\title{
Is 24,25-dihydroxycholecalciferol a calcium-regulating hormone in man?
}

\author{
J A KANIS, T CUNDY, M BARTLETT, R SMITH, G HEYNEN, G T WARNER, R G G RUSSELL
}

The fact that in adults the concentration of $24,25-(\mathrm{OH})_{2} \mathrm{D}_{3}$ in plasma is about 100 times $^{21 \cdots 23}$ that of $1,25-(\mathrm{OH})_{2} \mathrm{D}_{3}{ }^{24}{ }^{25}$ prompted us to examine its biological activity in man.

\section{Summary and conclusions}

Small doses (1-10 $\mu$ g daily) of 24,25-dihydroxycholecalciferol $\left(24,25-(\mathrm{OH})_{2} \mathrm{D}_{3}\right)$, a renal metabolite of vitamin $D$ of uncertain function, increased intestinal absorption of calcium in normal people and in patients with various disorders of mineral metabolism, including anephric subjects. In five of six patients studied, calcium balance increased, but, unlike 1,25-dihydroxycholecalciferol, 24,25- $(\mathrm{OH})_{2} D_{3}$ did not increase plasma or urinary calcium concentrations. These results suggest that 24,25- $(\mathrm{OH})_{2} \mathrm{D}_{3}$ may be an important regulator of skeletal metabolism in man with potential value as a therapeutic agent.

\section{Introduction}

Vitamin $\mathrm{D}_{3}$, derived from the diet or by the action of ultraviolet light on the skin, undergoes metabolic conversion before exerting its biological effects. ${ }^{1}$ ' The liver produces 25 -hydroxycholecalciferol, which the kidney then converts to 1,25-dihydroxycholecalciferol $\left(1,25-(\mathrm{OH})_{2} \mathrm{D}_{3}\right)$ and $24,25-(\mathrm{OH})_{2} \mathrm{D}_{3}$. The bulk of experimental evidence suggests that $1,25-(\mathrm{OH})_{2} \mathrm{D}_{3}$ is a major hormonally active form of vitamin $\mathrm{D}_{3}$, responsible for increasing intestinal absorption of calcium and phosphate, enhancing bone resorption, and preventing rickets. ${ }^{12}$ Defective renal synthesis of $1,25-(\mathrm{OH})_{2} \mathrm{D}_{3}$ is thought to contribute to abnormalities in mineral metabolism in renal osteodystrophy, vitamin $\mathrm{D}$ dependent rickets, hypoparathyroidism, and pseudohypoparathyroidism. ${ }^{3-6}$ By contrast, $24,25-(\mathrm{OH})_{2} \mathrm{D}_{3}$ seems to be much less active in various animals, ${ }^{7-15}$ and its function remains obscure.

In animals and birds the rate of renal synthesis of both $1,25-(\mathrm{OH})_{2} \mathrm{D}_{3}$ and $24,25-(\mathrm{OH})_{2} \mathrm{D}_{3}$ is regulated by various factors, including plasma concentrations of phosphate, calcium, parathyroid hormone, prolactin, oestrogens, and drugs. ${ }^{1}{ }^{16-18}$ The production of $1,25-(\mathrm{OH})_{2} \mathrm{D}_{3}$ and of $24,25-(\mathrm{OH})_{2} \mathrm{D}_{3}$ are often reciprocally related so that, as the production of one increases, that of the other diminishes. $24,25-(\mathrm{OH})_{2} \mathrm{D}_{3}$ may be synthesised in cartilage $\mathrm{e}^{19}$ and in intestinal mucosa ${ }^{20}$ as well as in the kidney, but the importance of these sites in man is unknown. In man synthesis of $1,25-(\mathrm{OH})_{2} \mathrm{D}_{3}$ is abolished ${ }^{1}{ }^{3}$ after nephrectomy, but whether $24,25-(\mathrm{OH})_{2} \mathrm{D}_{3}$ continues to be made is disputed. ${ }^{21} 22$

Nuffield Departments of Medicine and Orthopaedic Surgery,

University of Oxford, Oxford

J A KANIS, MRCP, Wellcome senior clinical research fellow

T CUNDY, MRCP, research fellow

$M$ BARTLETT, technician

R SMITH, MD, FRCP, consultant physician

G HEYNEN, MD, research fellow

G T WARNER, DPHIL, physicist

Department of Chemical Pathology, University of Sheffield, Sheffield

R G G RUSSELL, DM, MRCPATH, professor

\section{Patients and methods}

Intestinal calcium absorption was measured in 17 normal subjects and 13 patients with chronic renal failure treated by long-term $\vec{\omega}$ haemodialysis (Kiil Multipoint dialyser, 12-18 h/week). Seven of these patients were anephric. Six additional patients, who did not have 3 . chronic renal failure but had various other disorders of mineral metabolism, underwent metabolic balance studies. None of the patients had taken vitamin D or anticonvulsant drugs for at least six $\vec{N}$ months before the present study.

In all normal subjects and patients with chronic renal failure $\vec{\omega}$ calcium absorption was assessed on a total body counter"ii by the seven-day retention of an oral dose of ${ }^{17} \mathrm{Ca}$ given with $200 \mathrm{mg}$ calcium 응 as the gluconate. The patients and normal subjects fasted at least four hours before and two hours after the test dose. On completion of the first absorption test they were given the agent to be tested for seven 3 days. A second and similar dose of ${ }^{47} \mathrm{Ca}$ was given on the fourth day of treatment. Thus each evaluation comprised two separate determinations of calcium absorption. In four of the anephric patients and seven normal subjects a third calcium absorption test was done three days after stopping treatment to assess the duration of any response. The patients with chronic renal failure were always given the dose of ${ }^{17} \mathrm{Ca}$ at the same time in relation to their next dialysis treatment. The total body retention of ${ }^{4} \mathrm{Ca}$ was not corrected for losses of ${ }^{77} \mathrm{Ca}$ into the dialysate fluid or the urine, since these losses were too small to be measured accurately. The agents tested were $1,25-(\mathrm{OH})_{2} \mathrm{D}_{3}$ or $24,25-(\mathrm{OH})_{2} \mathrm{D}_{3}, 1-2 \mu \mathrm{g}(2 \cdot 4-4 \cdot 8 \mathrm{nmol})$ given daily by mouth for seven days. Several of the patients and normal subjects had their responses measured more than once (table I), but in each case a new baseline measurement of calcium absorption was made, and at least 14 days elapsed between treatments. Four of the patients and 13 normal subjects also underwent two calcium absorption tests but without administration of vitamin $\mathrm{D}$ metabolites between to assess the random fluctuations in the test.

Metabolic balances of calcium and inorganic phosphate were measured in the six patients without chronic renal failure who had various other disorders of mineral metabolism (see table II). Copper thiocyanate and carmine red were used as internal and external markers respectively. ${ }^{27}$ The diet prescribed was as close as possible to the patients' normal intake of calcium and phosphate and this was checked by regular analysis of samples of the diet. After four days of

TABLE I-Paired calcium absorption studies performed in 17 normal subjects and 13 patients with chronic renal failure

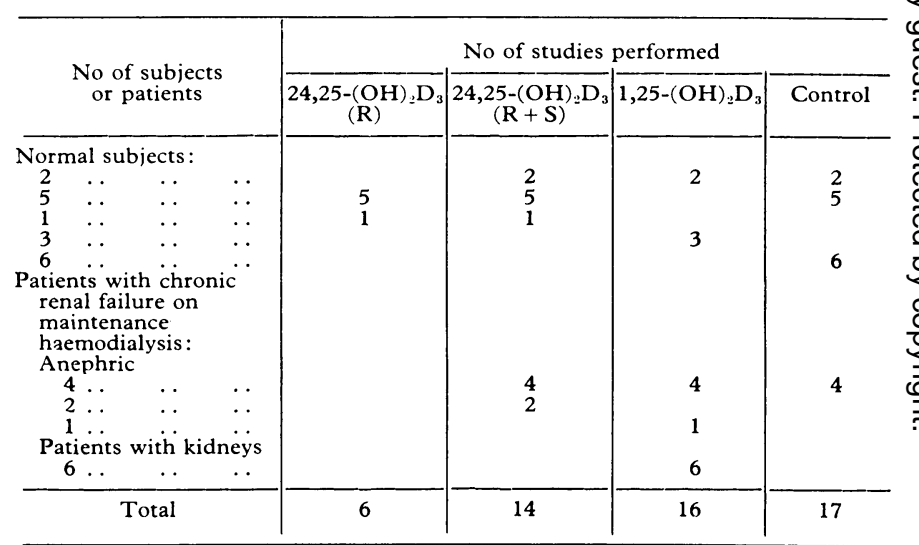


TABLE II-Details of patients studied and responses to $24,25-(\mathrm{OH})_{2} \mathrm{D}_{3}$. Balances were calculated as dietary intake minus (faecal plus urinary) excretion

\begin{tabular}{|c|c|c|c|c|c|c|c|c|c|c|c|}
\hline \multirow{2}{*}{$\begin{array}{l}\text { Case } \\
\text { No }\end{array}$} & \multirow[t]{2}{*}{ Diagnosis } & \multirow{2}{*}{$\begin{array}{l}\text { Age } \\
\text { and } \\
\text { sex }\end{array}$} & \multirow{2}{*}{$\begin{array}{c}\text { Body } \\
\text { weight } \\
(\mathrm{kg})\end{array}$} & \multicolumn{2}{|c|}{$\begin{array}{l}\text { Dietary intake } \\
(\mathrm{mmol} / \text { day })\end{array}$} & \multirow{2}{*}{$\begin{array}{c}\text { Consecutive } \\
4 \text {-day } \\
\text { balance } \\
\text { period }\end{array}$} & \multirow{2}{*}{$\begin{array}{c}\text { Dose of } \\
24,25- \\
(\mathrm{OH})_{2} \mathrm{D}_{3} \\
(\mu \mathrm{g} / \text { day })\end{array}$} & \multicolumn{2}{|c|}{$\begin{array}{l}\text { Urinary excretion } \\
(\mathrm{mmol} / \mathrm{day})\end{array}$} & \multicolumn{2}{|c|}{$\begin{array}{l}\text { External balance } \\
(\mathrm{mmol} / \text { day })\end{array}$} \\
\hline & & & & Calcium & Phosphate & & & Calcium & Phosphate & Calcium & Phosphate \\
\hline 1 & Idiopathic & $34 \mathrm{M}$ & $72 \cdot 7$ & $29 \cdot 7$ & $45 \cdot 8$ & 1 & $\begin{array}{l}0 \\
2+\end{array}$ & $\begin{array}{r}10 \cdot 4 \\
7.6\end{array}$ & $\begin{array}{l}20 \cdot 8 \\
27 \cdot 2\end{array}$ & $\begin{array}{r}+1 \cdot 6 \\
+13 \cdot 1^{+}\end{array}$ & $\begin{array}{r}+10 \cdot 6 \\
+3 \cdot 0\end{array}$ \\
\hline 2 & $\begin{array}{l}\text { Osteogenesis } \\
\text { imperfecta }\end{array}$ & $67 \mathrm{~F}$ & $73 \cdot 4$ & $9 \cdot 1$ & $20 \cdot 8$ & $\begin{array}{l}1 \\
2 \\
3 \\
4\end{array}$ & $\begin{array}{l}0 \\
0 \\
2+ \\
0\end{array}$ & $\begin{array}{l}1.8 \\
1.8 \\
2.0 \\
2.6\end{array}$ & $\begin{array}{l}15 \cdot 5 \\
14 \cdot 8 \\
12 \cdot 3 \\
13 \cdot 1\end{array}$ & $\begin{array}{l}-1.7 \\
-1.8 \\
-0.1 \ddagger \\
-2.3\end{array}$ & $\begin{array}{l}-1.3 \\
-0.7 \\
+3.6 \ddagger \\
+1.0\end{array}$ \\
\hline 3 & $\begin{array}{l}\text { Type I hypophosphataemic } \\
\text { osteomalacia }\end{array}$ & $64 \mathrm{~F}$ & $47 \cdot 5$ & $15 \cdot 2$ & $24 \cdot 5$ & $\begin{array}{l}4 \\
1 \\
2 \\
3 \\
4 \\
5\end{array}$ & $\begin{array}{r}0 \\
0 \\
0 \\
2 \\
0 \\
10\end{array}$ & $\begin{array}{l}1.5 \\
1.3 \\
1.2 \\
1.3 \\
1.3\end{array}$ & $\begin{array}{r}11 \cdot 1 \\
12 \cdot 5 \\
9 \cdot 2 \\
12 \cdot 2 \\
10 \cdot 4\end{array}$ & $\begin{array}{l}-3.1 \\
-2.5 \\
-0.5 \ddagger \\
-2.9 \\
-0.1 \ddagger\end{array}$ & $\begin{array}{l}0.0 \\
-2.0 \\
+3.3 \ddagger \\
-0.4 \\
+1.0\end{array}$ \\
\hline 4 & $\begin{array}{l}\text { Postsurgical } \\
\text { hypoparathyroidism }\end{array}$ & $61 \mathrm{~F}$ & $62 \cdot 6$ & $37 \cdot 3^{*}$ & $32 \cdot 0$ & 1 & $\begin{array}{l}0 \\
1\end{array}$ & $\begin{array}{l}3 \cdot 7 \\
3 \cdot 3 \\
3 \cdot 2\end{array}$ & $\begin{array}{l}18 \cdot 2 \\
15 \cdot 5 \\
15 \cdot 4\end{array}$ & $\begin{array}{l}+2 \cdot 1 \\
+2 \cdot 1 \\
+8 \cdot 9+\end{array}$ & $\begin{array}{l}+0 \cdot 2 \\
+0 \cdot 8 \\
+4 \cdot 7\end{array}$ \\
\hline 5 & $\begin{array}{l}\text { Idiopathic } \\
\quad \text { osteoporosis }\end{array}$ & $46 \mathrm{M}$ & $69 \cdot 8$ & $22 \cdot 5$ & $41 \cdot 1$ & $\begin{array}{l}3 \\
1 \\
2 \\
3\end{array}$ & $\begin{array}{r}10 \\
0 \\
0 \\
2\end{array}$ & $\begin{array}{l}3 \cdot 7 \\
4 \cdot 1 \\
4 \cdot 6\end{array}$ & $\begin{array}{l}23 \cdot 4 \\
28 \cdot 4 \\
24 \cdot 9\end{array}$ & $\begin{array}{l}-3.4^{+} \\
-4.5 \\
-5.0\end{array}$ & $\begin{array}{l}-0.6 \\
-6.7 \\
-3.3\end{array}$ \\
\hline 6 & $\begin{array}{l}\text { Idiopathic } \\
\text { hypoparathyroidism }\end{array}$ & $67 \mathrm{M}$ & $80 \cdot 9$ & $49 \cdot 3^{*}$ & $32 \cdot 0$ & $\begin{array}{l}4 \\
1 \\
2\end{array}$ & $\begin{array}{l}2 \\
0 \\
4\end{array}$ & $\begin{array}{l}4 \cdot 1 \\
1 \cdot 4 \\
2 \cdot 0\end{array}$ & $\begin{array}{r}24 \cdot 0 \\
10 \cdot 8 \\
9 \cdot 0\end{array}$ & $\begin{array}{l}-4 \cdot 8 \\
+2 \cdot 4 \\
+3.9\end{array}$ & $\begin{array}{l}-2.3 \\
-1.8 \\
+2.7\end{array}$ \\
\hline
\end{tabular}

*Dietary supplement of calcium. $\quad+R$ epimer; the rest received $\mathrm{R}+\mathrm{S}$. Comparison of results from two consecutive 4-day periods without treatment in 10 additional patients (not shown) showed that random fluctuation in balance did not exceed $+10^{\prime \prime}$, of dietary intake for calcium (mean difference $=2 \cdot 1^{\circ}{ }^{\prime \prime}$ ) or $\pm 15^{\circ}{ }_{\circ}^{\prime}$ for phosphate (mean difference

$=2 \cdot 3 "$ ". of dietary intake). IChanges in balance that exceeded random fluctuations.
Conversion: SI to traditional units-Calcium $1 \mathrm{mmol}$ day $\approx 40 \mathrm{mg}$ day. Phosphate: $1 \mathrm{mmol} / \mathrm{day} \approx 0.031 \mathrm{~g} /$ day

equilibration on the diet, during which the internal marker was given, the first external marker of carmine was taken. Faeces were then collected in four-day period delineated by carmine markers.

Calcium, inorganic phosphate, creatinine, alkaline phosphatase, and urinary hydroxyproline were measured by established techniques. ${ }^{28}$ Plasma was taken after an overnight fast from all patients except those on intermittent haemodialysis, whose samples were taken immediately before dialysis.

$1,25-(\mathrm{OH})_{2} \mathrm{D}_{3}$ and $24,25-(\mathrm{OH})_{2} \mathrm{D}_{3}$ were chemically synthesised and were a gift from Hoffmann-La Roche. ${ }^{29}$ Two batches of $24,25-(\mathrm{OH})_{2} \mathrm{D}_{3}$ were used. The first was a mixture of $24 \mathrm{R}$ and $\mathrm{S}$ epimer (predominantly $\mathrm{R}$ form) and more recently the pure $24 \mathrm{R}$ epimer was used in six normal subjects. ${ }^{*}$ The metabolites were dissolved in ethanol before use and stored in dark glass bottles at $4^{\circ} \mathrm{C}$ under argon. They were given by mouth in a single dose of $1-10 \mu \mathrm{g}(2 \cdot 4-24 \cdot 0 \mathrm{nmol})$. Aliquots of $24,25-(\mathrm{OH})_{2} \mathrm{D}_{3}$ examined from time to time by ultraviolet spectrophotometry and high-pressure liquid chromatography showed acceptable stability under these conditions.

The significance of differences between mean values was assessed by Student's $t$ test for paired and non-paired data as appropriate.

\section{Results}

INTESTINAL ABSORPTION OF CALCIUM

Intestinal absorption of ${ }^{4} \mathrm{Ca}$ was significantly lower $(\mathrm{P}<0.002)$ in patients with chronic renal failure than in normal subjects (fig 1). In eight normal subjects daily administration of $24,25-(\mathrm{OH})_{2} \mathrm{D}_{3}(\mathrm{R}$ and $\mathrm{S}$ form, $1 \mu \mathrm{g}$ daily, except one subject who was given $2 \mu \mathrm{g}$ daily) increased retention of ${ }^{4} \mathrm{Ca}$ (mean absorption $\pm \mathrm{SE}$ of mean) from $19.9 \pm 2.2 \%$ to $26.0 \pm 2.0 \%(\mathbf{P}<0.02$; fig 2$)$.

Six of the normal subjects subsequently took the pure $\mathrm{R}$ form of $24,25-(\mathrm{OH})_{2} \mathrm{D}_{3}$, and their mean calcium absorption increased from $17.5 \pm 2.5 \%$ to $22.5 \pm 1.7 \% \quad(P<0.02)$. Comparison between the efficacy of the two batches of $24,25-(\mathrm{OH})_{2} \mathrm{D}_{3}$ showed no difference in the mean increment noted (mean increment ( \pm SE of mean) $24 \mathrm{R}$, + $5 \cdot 0 \pm 1 \cdot 2 \% ; 24 \mathrm{R}+\mathrm{S},+6 \cdot 1 \pm 1 \cdot 8 \%$.

In the six anephric patients given $24,25-(\mathrm{OH})_{2} \mathrm{D}_{3}$ calcium absorption also increased during its administration (from $10.5 \pm 1.8 \%$ to $24 \cdot 2 \pm 6.9 \%$; fig 2 ) to levels found in healthy people (fig 1 ).

Calcium absorption was measured three days after stopping $24,25-(\mathrm{OH})_{2} \mathrm{D}_{3}$ in four anephric patients and seven normal subjects. Absorption of ${ }^{47} \mathrm{Ca}$, which had increased during the treatment period, fell thereafter to pretreatment levels (fig 3).

Using the same protocol, calcium absorption was measured in five normal subjects and 11 patients with chronic renal failure on maintenance haemodialysis (five anephric) before and during the administration of $1,25-(\mathrm{OH})_{2} \mathrm{D}_{3}(1 \mathrm{~kg}$ daily) by mouth. Calcium absorption increased in all groups (fig 2) and the increment noted in

*The nomenclature refers to the spatial position of the 24-hydroxyl group on the side chain of vitamin $D_{3}$. The $R$ form is thought to be the epimer that is produced biologically. ${ }^{8}$

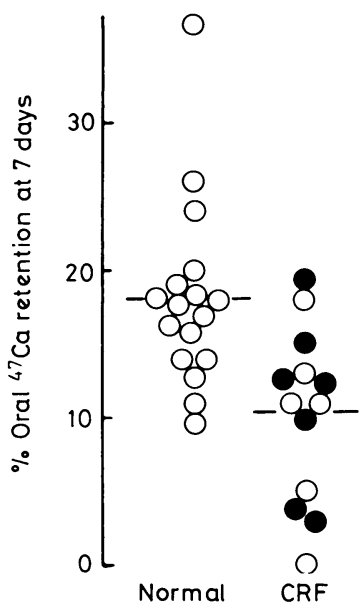

FIG 1 -Intestinal absorption of calcium $\left({ }^{47} \mathrm{Ca}\right.$ retention) in 17 normal subjects and 13 patients treated by intermittent haemodialysis for end-stage chronic renal failure (CRF). Those with chronic renal failure had lower absorption $(P<0.02)$ with no obvious difference between patients with $(O)$ and without $(O)$ kidneys.

calcium absorption (mean $=8.5 \%$ ) was similar to that observed after administration of $24,25-(\mathrm{OH})_{2} \mathrm{D}_{3}$ (mean $=7 \cdot 8 \%$ ). Control studies in 13 subjects and four patients showed that the mean variation between two calcium absorption tests repeated when no treatment was given was not significantly different from 0 (mean difference $\pm S E$ of mean between first and second absorption tests was $0.5 \pm 1.4 \%$ ). The changes in calcium absorption seen after administration of either dihydroxy metabolite were significantly greater $(P<0.01)$.

\section{BALANCE STUDIES}

$24,25-(\mathrm{OH})_{2} \mathrm{D}_{3}$ given daily by mouth at doses of 1 to $10 \mu \mathrm{g}$ increased the retention of calcium in five of the six patients investigated (range $=1.7-11.5 \mathrm{mmol} /$ day $(68-460 \mathrm{mg} /$ day); table II) due to an increase in the net intestinal absorption of calcium. One patient (case 4) showed no response when given $1 \mu \mathrm{g}$ daily for four days but the balance increased considerably when the dose was increased to $10 \mu \mathrm{g}$ daily.

Another patient (case 5) who was given $2 \mu \mathrm{g}$ for two four-day periods also showed no change in absorption or balance of calcium, whereas a subsequent study using $1,25-(\mathrm{OH})_{2} \mathrm{D}_{3}(2 \mu \mathrm{g}$ daily for 8 days) produced a considerable increase in calcium balance (from -2.6 to $+3.3 \mathrm{mmol} /$ day ( -104 to $+132 \mathrm{mg} /$ day $)$ ).

In two patients (cases 2 and 3 ) in whom balance studies were continued after stopping $24,25-(\mathrm{OH})_{2} \mathrm{D}_{3}$, the net absorption and the 


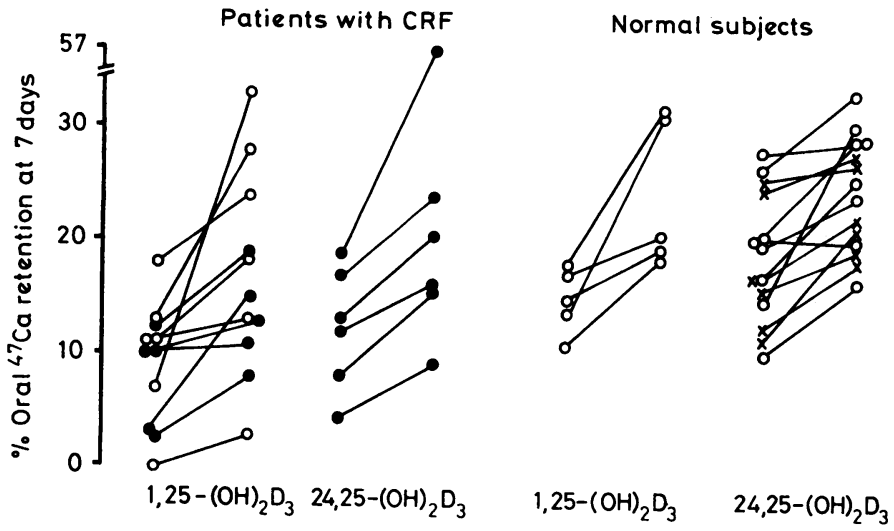

FIG 2-Intestinal absorption of calcium before and on the 4 th day of treatment with $1,25-(\mathrm{OH})_{2} \mathrm{D}_{3}$ or $24,25-(\mathrm{OH})_{2} \mathrm{D}_{3}$ at $1 \mu \mathrm{g}$ daily by mouth for seven days (except one normal person given $2 \mu \mathrm{g}$ of each daily). Six of the 8 normal subjects also received the $R$ epimer of $24,25-(\mathrm{OH})_{2} \mathrm{D}_{3}$ (denoted $\mathrm{X}$ ) in a separate study. The remaining subjects and patients received a mixture of $\mathbf{R}$ and $\mathbf{S}$ epimers (predominantly $\mathbf{R}$ ). D Denotes anephric patients.

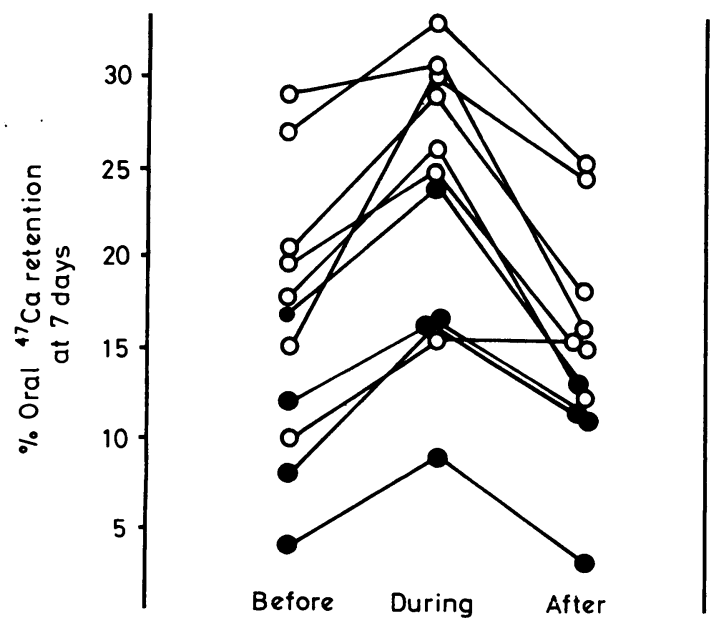

FIG 3-Intestinal absorption of calcium measured before and four days after starting a seven-day course of 24,25$(\mathrm{OH})_{2} \mathrm{D}_{3}(\mathrm{R}+\mathrm{S}$ epimers) at $1 \mu \mathrm{g} /$ day. Absorption was remeasured three days after stopping $24,25-(\mathrm{OH})_{2} \mathrm{D}_{3}$ in the four anephric patients $(O)$ and 7 normal subjects $(O)$. Note return of absorption values towards baseline when treatment was stopped.

balance of calcium rapidly reverted to that noted before treatment (fig 4), as had also been found in the ${ }^{47} \mathrm{Ca}$ absorption studies (fig 3 ).

$24,25-(\mathrm{OH})_{2} \mathrm{D}_{3}$ also increased the balance of phosphate but the effects were less consistent than those on calcium balance (table II fig 4). Urinary excretion of hydroxyproline measured in six subjects before and at the end of treatment did not change significantly (mean $\pm \mathrm{SE}$ of mean, $311 \pm 136 \mu \mathrm{mol} / 24 \mathrm{~h}(40.8 \pm 17.8 \mathrm{mg} / 24 \mathrm{~h}$ ) and $328 \pm 163 \mu \mathrm{mol} / 24 \mathrm{~h}(43.0 \pm 21.4 \mathrm{mg} / 24 \mathrm{~h})$ respectively).

\section{PLASMA AND URINARY CALCIUM}

Plasma calcium concentrations did not change consistently with $24,25-(\mathrm{OH})_{2} \mathrm{D}_{3}$ (mean $\pm \mathrm{SE}$ of mean before, $2.26 \pm 0.08 \mathrm{mmol} /$ $(9.0 \pm 0.32 \mathrm{mg} / 100 \mathrm{ml}) ;$ after, $2.22 \pm 0.08 \mathrm{mmol} / 1(8.9 \pm 0.32 \mathrm{mg} / 100$ $\mathrm{ml})$ in the balance studies. In contrast, $1,25-(\mathrm{OH})_{2} \mathrm{D}_{3}$ or $1-\alpha-$ hydroxycholecalciferol $\left(1-\alpha-\mathrm{OHD}_{3}\right)$ under comparable conditions raised plasma calcium concentrations (fig $5 \mathrm{a}$ ).

A notable feature of all the balance studies was that, despite increases in the net absorption of calcium during treatment, the daily urinary excretion of calcium did not increase during treatment with 24,25$(\mathrm{OH})_{2} \mathrm{D}_{3}$ (table II). This effect was verified in further studies. Thus in a normal subject urinary calcium did not increase when $2 \mu \mathrm{g}$ of $24,25-(\mathrm{OH})_{2} \mathrm{D}_{3}$ was given daily for seven days, whereas the same dose of $1,25-(\mathrm{OH})_{2} \mathrm{D}_{3}$ caused an increase. In the same subject the increase noted in the intestinal absorption of ${ }^{47} \mathrm{Ca}$ was, however, similar during the administration of both metabolites (fig $5 \mathrm{~b}$ ). In two further patients (cases 3 and 4) the excretion rate of calcium increased during treatment with $1,25-(\mathrm{OH})_{2} \mathrm{D}_{3}$ or $1-\alpha-(\mathrm{OH})_{2} \mathrm{D}_{3}$ but not with $24,25-$ $(\mathrm{OH})_{2} \mathrm{D}_{3}$ (fig 5a and $\mathrm{c}$ ), despite comparable increases in the net intestinal absorption of calcium with each of the compounds.

\section{PLASMA AND URINARY PHOSPHATE}

Plasma phosphate concentrations, measured in the balance studies, $\vec{\Rightarrow}$ did not change consistently (mean $\pm S E$ of mean before, $1.09 \pm 0.13 \stackrel{\text { S }}{?}$ $\mathrm{mmol} / 1$ ( $3.4 \pm 0.4 \mathrm{mg} / 100 \mathrm{ml}) ;$ after, $1.11 \pm 0.16 \mathrm{mmol} / 1(3.4 \pm 0.5 \mathrm{C}$ $\mathrm{mg} / 100 \mathrm{ml}$ ). Mean urinary phosphate did not change significantly but음 in some patients it fell slightly (table II and fig 4).

\section{Discussion}

These results show that microgram doses of chemically synthesised $24,25-(\mathrm{OH})_{2} \mathrm{D}_{3}$ increase the intestinal absorption of ${ }^{\omega}$ calcium as measured by two independent techniques-namely, $D$

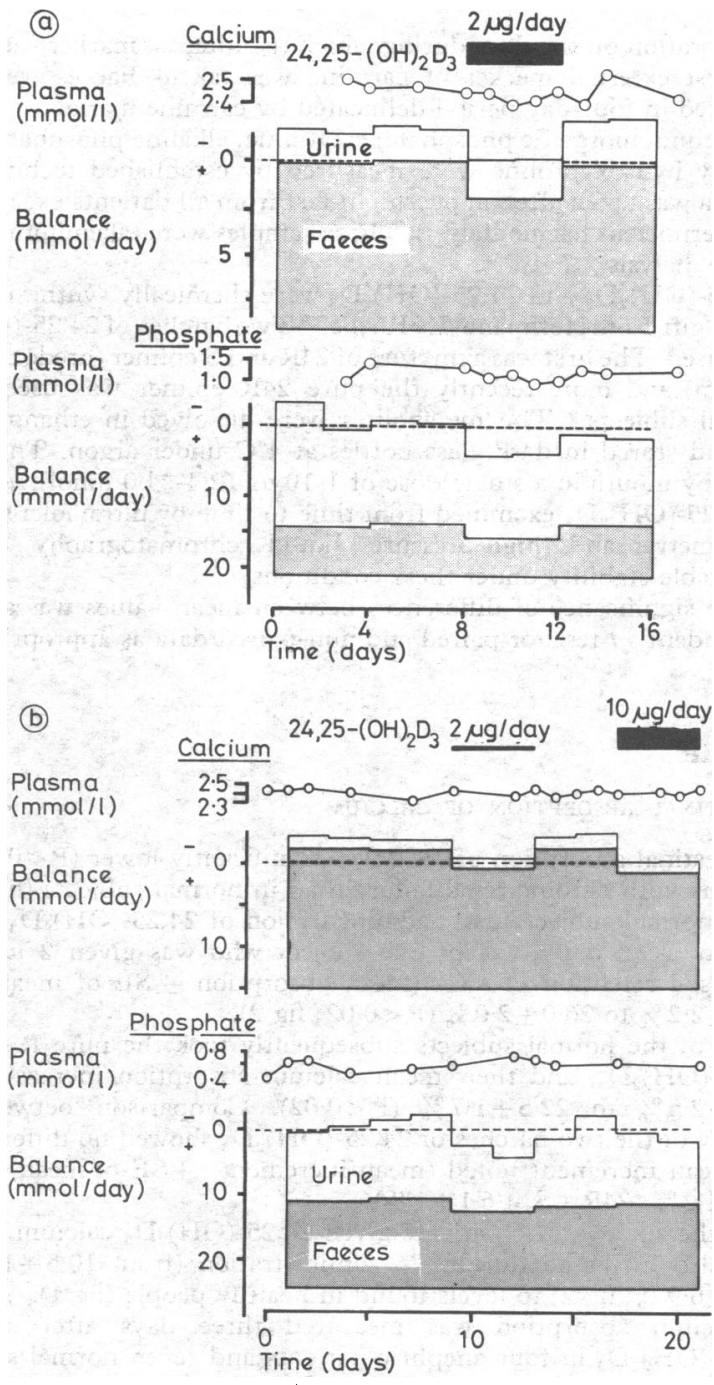

FIG 4-Effect of $24,25-(\mathrm{OH})_{2} \mathrm{D}_{3}$ on balance and plasma concentrations of calcium and phosphate in $(a)$ patient with osteogenesis imperfecta (case 2) and $(b)$ one with type I hypophosphataemia (case 3 ). In both patients administration of $24,25-(\mathrm{OH})_{2} \mathrm{D}_{3}$ increased the absorption and balance of calcium without increasing plasma or urine calcium. In both patients balance of phosphate also became positive during treatment.

Conversion: SI to traditional units-Calcium: $1 \mathrm{mmol} / 1 \approx 4$ $\mathrm{mg} / 100 \mathrm{ml} ; 1 \mathrm{mmol} /$ day $\approx 10 \mathrm{mg} /$ day. Phosphate: $1 \mathrm{mmol} / 1$ $\approx 3.1 \mathrm{mg} / 100 \mathrm{ml} ; 1 \mathrm{mmol} /$ day $\approx 0.031 \mathrm{~g} /$ day. 


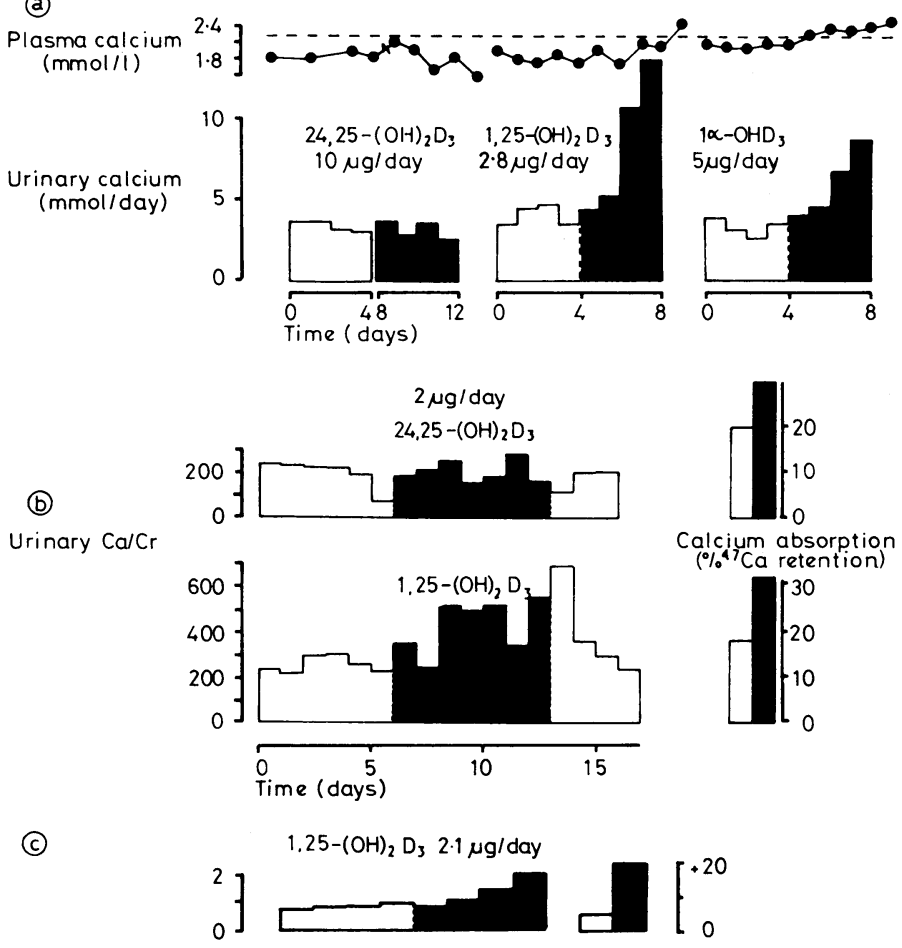

$24.25-(\mathrm{OH})_{2} \mathrm{D}_{3} 10 \mu \mathrm{g} / \mathrm{day}$
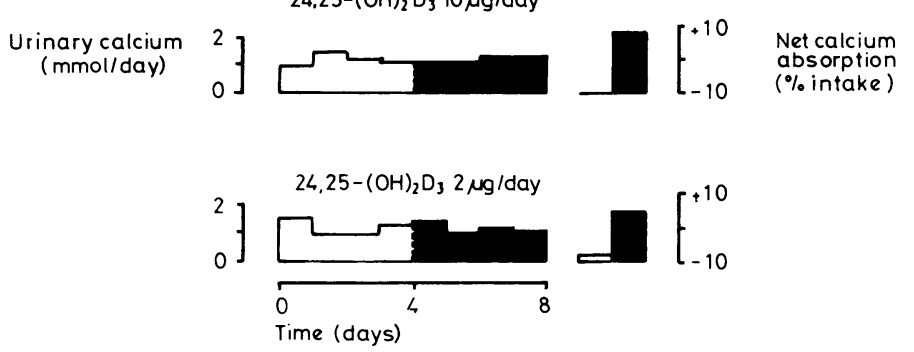

FIG 5-Effect of vitamin D metabolites on urinary excretion of calcium. (a) Patient (case 4) with hypoparathyroidism was studied in each instance on a constant diet. Metabolites were given by mouth for 4 days (shaded area) after 4 days' observation. The synthetic $1-\alpha-\mathrm{OHD}_{3}$ was supplied by Leo Laboratories. (b) Normal subject on unrestricted diet. Urinary calcium was expressed as ratio of calcium to creatinine excreted. Calcium absorption was measured (total body counter) on the 4th day of administration of metabolite (shaded areas) and compared with values obtained one week before (unshaded). (c) Patient with type I hypophosphataemia (case 3) studied under balance conditions. Net intestinal absorption of calcium was calculated from the balance studies. Increases in intestinal absorption, urinary excretion, and plasma concentrations of calcium occurred during administration of $1,25-$ $(\mathrm{OH})_{2} \mathrm{D}_{3}$ or 1- $\alpha$-hydroxycholecalciferol, but $24,25-(\mathrm{OH})_{2} \mathrm{D}_{3}$ had no effect on plasma or urine calcium despite comparable increments in calcium absorption.

the absorption of ${ }^{47} \mathrm{Ca}$ and external balance. The increase in ${ }^{4} \mathrm{Ca}$ absorption was shown to be significantly greater $(\mathrm{P}<0 \cdot 01)$ than the test-to-test variation observed in untreated patients. Moreover, in the balance studies four of the six patients showed a significant increase in calcium retention of more than $10^{\circ}{ }_{0}$. The effect on calcium absorption was quantitatively similar to that observed with $1,25-(\mathrm{OH})_{2} \mathrm{D}_{3}$ at comparable doses.

At first sight these findings seem to conflict with observations made in mammals and birds, which suggest that $1,25-(\mathrm{OH})_{2} \mathrm{D}_{3}$ is the major biologically active derivative of vitamin $\mathrm{D}$ and accounts for all known actions of the vitamin. Although $24,25-(\mathrm{OH})_{2} \mathrm{D}_{3}$ is more active in mammals than in birds, ${ }^{1}{ }^{7-10} 1214$ the doses of $24,25-(\mathrm{OH})_{2} \mathrm{D}_{3}$ required to stimulate intestinal absorption of calcium and phosphate in these species are one to two orders of magnitude higher than those of $1,25-(\mathrm{OH})_{2} \mathrm{D}_{3}$. The $\mathrm{R}$ epimer rather than the $24 \mathrm{~S}$ is the natural form, ${ }^{8}{ }^{9}$ but even this seems to require conversion to $1,24,25$-trihydroxyvitamin $\mathrm{D}$ in the kidney to express its full biological activity, since in the doses so far used in nephrectomised animals $24,25-(\mathrm{OH})_{2} \mathrm{D}_{3}$ is inactive. ${ }^{910} \mathrm{By}$ contrast, in our study $24,25-(\mathrm{OH})_{2} \mathrm{D}_{3}$ increased calcium absorption even in anephric subjects, indicating that in man the renal 1-hydroxylase system is not essential for its activity.

Comparisons of potency between $1,25-(\mathrm{OH})_{2} \mathrm{D}_{3}$ and $24,25-$ $(\mathrm{OH})_{2} \mathrm{D}_{3}$ may depend critically on the method used, since dissimilar results may be obtained in different experimental systems. For example, $24,25-(\mathrm{OH})_{2} \mathrm{D}_{3}$ is only 20 times less active than $1,25-(\mathrm{OH})_{2} \mathrm{D}_{3}$ in stimulating the biosynthesis of calciumbinding protein in isolated chick duodenum, ${ }^{30}{ }^{31}$ whereas its affinity for the isolated intestinal receptor protein is about a thousand times less than that of $1,25-(\mathrm{OH})_{2} \mathrm{D}_{3}{ }^{32}$ When experiments are done in vivo, comparisons of potency will also depend on the metabolic clearance rates of the respective metabolites. There is evidence in man that the metabolic clearance rate of $24,25-(\mathrm{OH})_{2} \mathrm{D}_{3}$ is much lower than that of $1,25-(\mathrm{OH})_{2} \mathrm{D}_{3}$ and the biological half life is several weeks rather than one to three days. ${ }^{11}{ }^{33} 3^{34}$ This difference may explain the hundredfold greater concentration of $24,25-(\mathrm{OH})_{2} \mathrm{D}_{3}$ in plasma than that of $1,25-$ $(\mathrm{OH})_{2} \mathrm{D}_{3}{ }^{5}{ }^{25} 353^{36}$ despite the similarity of their production rates. ${ }^{136}$ These differences in metabolic turnover rates might help to explain apparent differences in relative potencies between birds, mammals, and man. The small doses used in our study might have produced higher and more sustained increases in plasma $24,25-(\mathrm{OH})_{2} \mathrm{D}_{3}$ than might otherwise have been expected but it is difficult to explain why the effect of $24,25-(\mathrm{OH})_{2} \mathrm{D}_{3}$ was so rapidly reversed. One explanation for this might be that $24,25-(\mathrm{OH})_{2} \mathrm{D}_{3}$ is particularly effective on intestinal calcium transport after oral administration, because it has a direct effect on the intestinal mucosa without requiring prior absorption into the systemic circulation. Its effects may therefore wear off rapidly owing to intestinal cell renewal when it is stopped. The type of test used to detect the effect may also be important, since isotopic tests in particular may give differing results, depending on the amount of calcium used as a carrier and the method of computing absorption.

Since the effect of $24,25-(\mathrm{OH})_{2} \mathrm{D}_{3}$ was seen with doses which can be calculated to be close to the daily endogenous production rate, possibly $24,25-(\mathrm{OH})_{2} \mathrm{D}_{3}$ is an additional hormone of physiological importance in regulating calcium metabolism. To support this suggestion there is evidence in other systems that physiological doses of $24,25-(\mathrm{OH})_{2} \mathrm{D}_{3}$ may have distinct biological effects that sometimes differ from those of 1,25$(\mathrm{OH})_{2} \mathrm{D}_{3}$. Thus, they have opposing effects on the secretion of parathyroid hormone, ${ }^{37}{ }^{38}$ and $24,25-(\mathrm{OH})_{2} \mathrm{D}_{3}$ but not $1,25-$ $(\mathrm{OH})_{2} \mathrm{D}_{3}$ may promote the biosynthesis and sulphation of glycosaminoglycans by isolated cartilage cells. ${ }^{19}$ In our studies in man the main difference between $24,25-(\mathrm{OH})_{2} \mathrm{D}_{3}$ and 1,25$(\mathrm{OH})_{2} \mathrm{D}_{3}$ was their contrasting effects on urinary calcium. Possibly $1,25-(\mathrm{OH})_{2} \mathrm{D}_{3}$ increases urinary calcium (and 24,25$(\mathrm{OH})_{2} \mathrm{D}_{3}$ does not) because it raises plasma calcium concentrations, possibly because of a greater enhancement of bone resorption. ${ }^{1315} 39$ The fate of the extra calcium absorbed during the administration of $24,25-(\mathrm{OH})_{2} \mathrm{D}_{3}$ is unknown, but presumably it goes to the skeleton. Possibly, although 24,25$(\mathrm{OH})_{2} \mathrm{D}_{3}$ and $1,25-(\mathrm{OH})_{2} \mathrm{D}_{3}$ are both able to cure rickets in animals, ${ }^{810} \quad 24,25-(\mathrm{OH})_{2} \mathrm{D}_{3}$ preferentially promotes calcium accretion in the skeleton because it does not simultaneously augment resorption of bone. Indeed, urinary hydroxyproline did not change in these short-term studies.

We conclude that $24,25-(\mathrm{OH})_{2} \mathrm{D}_{3}$ enhances intestinal absorption of calcium and phosphate in man and may have a part to play in maintaining adequate skeletal mineralisation. Its slow turnover time would make it an ideal long-acting hormone for promoting skeletal mineralisation, whereas $1,25-(\mathrm{OH})_{2} \mathrm{D}_{3}$, with its more rapid turnover rate, might be more suited for shorter-term regulation of the extracellular concentration of calcium and phosphate. Obviously several questions about the possible physiological role of $24,25-(\mathrm{OH})_{2} \mathrm{D}_{3}$ remain unanswered. Nevertheless, our results suggest that $24,25-(\mathrm{OH})_{2} \mathrm{D}_{3}$ deserves consideration as a possible therapeutic agent for 
promoting calcium retention in patients with bone-losing states such as osteoporosis.

We are grateful to the many patients and colleagues who have helped in this work, especially to Miss S Bacon, our dietician. We also thank the Wellcome Trust, The National Kidney Research Fund, and the Peel Medical Research Trust who have helped to support these studies.

\section{References}

${ }^{1}$ DeLuca, H F, and Schnoes, H K, Annual Review of Biochemistry, 1976, 45, 631 .

${ }^{2}$ Norman, A W, Friedlander, E J, and Henry, H, Advances in Experimental Medicine and Biology, 1977, 81, 211.

3 Mawer, E B, et al, Lancet, 1973, 1, 626

+ Fraser, D, et al, New England fournal of Medicine, 1973, 289, 817.

${ }^{5}$ Haussler, M R, et al, Vitamin D. Biochemical, Chemical and Clinical Aspects related to Calcium Metabolism, ed A W Norman, et al, p 473 Berlin, DeGruyter, 1977.

${ }^{6}$ Coburn, J W, Hartenbower, D L, and Brickman, A S, American fournal of Clinical Nutrition, 1976, 29, 1283.

${ }^{7}$ Holick, M F, et al, fournal of Biological Chemistry, 1976, 251, 397.

${ }^{8}$ Tanaka, Y, et al, Biochemistry, 1975, 14, 3293.

9 Tanaka, Y, et al, Archives of Biochemistry and Biophysics, 1975, 170, 620.

${ }_{10}$ Boyle, I T, et al, fournal of Biological Chemistry, 1973, 248, 4174.

11 Thomasset, M, et al, Vitamin D. Biochemical, Chemical and Clinical Aspects related to Calcium Metabolism, ed A W Norman, et al, p 619. Berlin, DeGruyter, 1977.

12 Boris, A, Hurley, J F, and Trinal, T, fournal of Nutrition, 1977, 107, 194

13 Stern, P H, et al, Vitamin D. Biochemical, Chemical and Clinical Aspects related to Calcium Metabolism, ed A W Norman, et al, p 531. Berlin, DeGruyter, 1977.

${ }^{14}$ Chen, T C, et al, fournal of Nutrition, 1974, 104, 1056.

${ }^{15}$ Reynolds, J J, Holick, M F, and DeLuca, H F, Calcified Tissue Research, $1974,15,333$

${ }^{16}$ MacIntyre, I, Vitamin D. Biochemical, Chemical and Clinical Aspects related to Calcium Metabolism, ed A W Norman, et al, p 155. Berlin, DeGruyter, 1977.
${ }^{17}$ DeLuca, H F, Advances in Experimental Medicine and Biology, 1977, 81, 195.

18 Baxter, L A, et al, Archives of Biochemistry and Biophysics, 1974, 164, 655.

19 Garebedian, M, et al, Proceedings of the 6th Parathyroid Conference, ed D H Copp and R V Talmage, p 372. Amsterdam, Excerpta Medica, 1978.

20 DeLuca, H F, and Schnoes, H K, Procedeings of the 6th Parathyroid Conference, ed D H Copp and R V Talmage. Amsterdam, Excerpta Medica, 1978

${ }^{21}$ Taylor, C M, Vitamin D. Biochemical, Chemical and Clinical Aspects related to Calcium Metabolism, ed A W Norman, et al, p 541. Berlin, DeGruyter, 1977.

${ }^{22}$ Haddad, J G, Min, C, and Waltgate, M, Vitamin D. Biochemical and Aspects related to Calcium Metabolism, ed A W Norman, et al, p 463. Berlin, DeGruyter, 1977.

23. Taylor, C M, Hughes, S E, and deSilva, P, Biochemica Biophysica Research Communications, 1976, 70, 1243.

${ }^{24}$ Haussler, M R, et al, Clinical Endocrinology, 1976, 5, Suppl p 151.

${ }^{25}$ Eisman, J A, et al, Archives of Biochemistry and Biophysics, 1976, 176, 235.

${ }^{26}$ Warner, G T, and Oliver, R, Physics in Medicine and Biology, 1966, 11, 83.

27 Dick, M, Gut, 1969, 10, 408.

${ }^{28}$ Smith, R, et al, Quarterly fournal of Medicine, 1973, 42, 235

${ }^{29}$ Uskokovic, M R, et al, Vitamin $D$ and Problems related to Uraemic Bone Disease, ed A W Norman, et al, p 279. Berlin, DeGruyter, 1975.

30 Parkes, C O, Proceedings of the 6th Parathyroid Conference, ed D H Copp and R V Talmage, p 165. Amsterdam, Excerpta Medica, 1978.

31 Corradino, R A, Vitamin D. Biochemical, Chemical and Clinical Aspects related to Calcium Metabolism, ed A W Norman, et al, p 231. Berlin, DeGruyter, 1977.

${ }^{32}$ Brumbaugh, P F, and Haussler, M R, fournal of Biological Chemistry, 1975, 250, 1588

33 Mawer, E B, et al, Lancet, 1976, 1, 1203

${ }^{34}$ Kanis, J A, and Russell, R G G, British Medical fournal, 1977, 1, 78

35 Taylor, C M, personal communication.

${ }^{6}$ Mawer, E B, et al, Clinical Science and Molecular Medicine, 1975, 48, 349.

'Care, A D, et al, Vitamin D. Biochemical, Chemical and Clinical Aspects related to Calcium Metabolism, ed A W Norman, et al, p 105. Berlin, DeGruyter, 1977

${ }^{38}$ Henry, H L, Wecksler, W R, and Norman, A W, Proceedings of the 6th Parathyroid Conference, ed D H Copp and R V Talmage, p 197. Amsterdam, Excerpta Medica, 1978.

${ }^{39}$ Raisz, L G, et al, Science, 1972, 175, 768.

\title{
Beta-blockers: once or three times a day?
}

\author{
T REYBROUCK, A AMERY, R FAGARD, P JOUSTEN, P LIJNEN, E MEULEPAS
}

British Medical fournal, 1978, 1, 1386-1388

\section{Summary and conclusions}

In a double-blind, crossover trial 16 hypertensive patients were treated, in random order, with placebo, metoprolol $300 \mathrm{mg}$ in a single daily dose, or metoprolol $300 \mathrm{mg} /$ day in three doses. Both therapeutic regimens produced detectable plasma metoprolol concentrations and appreciable beta-blockade, estimated from exercise tachycardia, throughout the day. Fluctuations throughout the

day in plasma drug concentrations and degree of betablockade were insignificant on the thrice-daily regimen, but they varied considerably on the single-dose regimen. Both therapeutic regimens also significantly lowered blood pressure throughout the day. Although the thricedaily regimen again tended to produce a stronger and less fluctuating hypotensive action, the differences in hypotensive effect between the two regimens were not statistically significant.

A single-dose of $300 \mathrm{mg}$ of metoprolol can therefore be recommended if the only aim is to reduce blood pressure but not if a steady degree of beta-blockade is needed.

\section{Introduction}

Ensuring that patients comply with their therapeutic regimen is a major problem in the long-term treatment of hypertension, especially if they are free of symptoms. The simpler the regimen the easier it should be for patients to comply. We describe a study performed to investigate whether the same degree of $\beta$-blockade and blood pressure control could be obtained throughout the day with a once-daily dose of the $\beta$-blocking agent metoprolol as with a thrice-daily regimen.

A AMERY, MD, professor of medicine

P JOUSTEN, MD, resident

P LIJNEN, PHD, research assistant

Department of Human Biology, Section of Human Heredity, University of Leuven, Leuven, Belgium

E MEULEPAS, DSC, professor in statistics 